\title{
Synthesis of Iron-Doped Zirconium Titanate as a Potential Visible-Light Responsive Photocatalyst
}

\author{
Rian Kurniawan, Sri Sudiono, Wega Trisunaryanti, and Akhmad Syoufian* \\ Department of Chemistry, Faculty of Mathematics and Natural Sciences, Universitas Gadjah Mada, \\ Sekip Utara, Yogyakarta 55281, Indonesia
}

* Corresponding author:

email:akhmadsyoufian@ugm.ac.id

Received: September 7, 2018

Accepted: December 13, 2018

DOI: $10.22146 / \mathrm{ijc} .38616$

\begin{abstract}
Synthesis and characterization of iron-doped zirconium titanate $\left(\mathrm{ZrTiO}_{4}\right)$ as a potential visible-light-responsive photocatalyst had been conducted. Various iron dopant concentrations and calcination temperature were investigated toward the properties of Fe-doped $\mathrm{ZrTiO}_{4}$. The photocatalyst material was synthesized by sol-gel and impregnation method. Titanium tetraisopropoxide (TTIP) was used as a precursor, embedded on zirconia fine powder. A certain amount of iron (1, 3, 5, 7 and 9 wt.\%) was introduced into the photocatalyst system from iron(II) sulfate heptahydrate $\left(\mathrm{FeSO}_{4} \cdot 7 \mathrm{H}_{2} \mathrm{O}\right)$. Photocatalyst with various iron concentrations was calcined at $500{ }^{\circ} \mathrm{C}$. $\mathrm{ZrTiO}_{4}$ with $5 \%$ iron was calcined at 700 and $900^{\circ} \mathrm{C}$. Characterization was performed by using XRD, FT-IR, SR-UV, and SEM-EDX. The presence of iron on the surface of $\mathrm{ZrTiO}_{4}$ was proved by EDX analysis. $\mathrm{Fe}$-doped $\mathrm{ZrTiO}_{4}$ with the lowest bandgap $(2.83 \mathrm{eV})$ is $7 \%$ of iron content after calcination at $500{ }^{\circ} \mathrm{C}$.
\end{abstract}

Keywords: Fe-doped $\mathrm{ZrTiO}_{4}$; photocatalyst; iron; dopant; bandgap

\section{- INTRODUCTION}

Zirconium dioxide or zirconia $\left(\mathrm{ZrO}_{2}\right)$ is one of the potential materials for photocatalysis due to its unique properties. It exhibits a high refractive index, optical transparency, high corrosive resistance, high mechanical properties, high thermal expansion, low thermal conductivity, high chemical and photothermal stability [1]. Wide bandgap of $\mathrm{ZrO}_{2}(\sim 5 \mathrm{eV})$ gives very strong photo-generated redox ability under ultra-violet (UV) irradiation [2]. Apparently, due to its wide bandgap, $\mathrm{ZrO}_{2}$ is not effective under solar irradiation.

Titanium dioxide $\left(\mathrm{TiO}_{2}\right)$ is considered as the most potential photocatalyst material due to its relatively strong oxidizing power under UV irradiation, high chemical stability, relatively cheap, and environmentally friendly [3]. Titanium dioxide or titania exists in four polymorphs which are anatase, rutile, brookite, and $\mathrm{TiO}_{2}(\mathrm{~B})$. Rutile is the most stable form at ambient pressure and temperature in macroscopic sizes while anatase is more stable in nanoscopic sizes [4]. The bandgap is $3.0 \mathrm{eV}$ for rutile and $3.2 \mathrm{eV}$ for anatase [5]. By combining $\mathrm{TiO}_{2}$ with $\mathrm{ZrO}_{2}$, it will produce a composite material called zirconium titanate $\left(\mathrm{ZrTiO}_{4}\right)$ which expected to have a smaller bandgap than that of $\mathrm{ZrO}_{2}$.

Zirconium titanate is a semiconductor material with high dielectric properties and very corrosive resistant. It exists in the orthorhombic structure at $400{ }^{\circ} \mathrm{C}$ calcination. Its bandgap was reported to be around $3.4 \mathrm{eV}$, which is relatively more photo-active than $\mathrm{ZrO}_{2}$ [6]. Other study had shown the potential application of $\mathrm{ZrTiO}_{4}$ as a photocatalyst material, but it does not perform as efficiently as $\mathrm{TiO}_{2}$ because of its relatively wide bandgap [7]. Thi et al. investigated the calcination temperature of the $\mathrm{ZrTiO}_{4}$ system towards the bandgap. Higher calcined $\mathrm{ZrTiO}_{4}$ has a wide bandgap [8].

Iron(III) metal ion $\left(\mathrm{Fe}^{3+}\right)$ was proved to be good dopant for increasing photocatalytic performance of $\mathrm{TiO}_{2}$. Due to its ionic radii similar to $\mathrm{Ti}^{4+}, \mathrm{Fe}^{3+}$ is able to incorporate into the $\mathrm{TiO}_{2}$ crystal structure and acts as a recombination center. The $\mathrm{d}^{5}$ valence electronic configuration of $\mathrm{Fe}^{3+}$ increases stability [3]. Incorporation of $\mathrm{Fe}^{3+}$ into $\mathrm{ZrO}_{2}$ crystal structure also decreases the bandgap and increases the photocatalytic activity, although its efficiency is still low if compared to $\mathrm{TiO}_{2}$ 
system [9]. By introducing $\mathrm{Fe}^{3+}$ ion into $\mathrm{ZrTiO}_{4}$ crystal structure, it will shift the bandgap and increase absorption efficiency towards visible light.

Several works have reported that modifications to shift the absorption of $\mathrm{ZrTiO}_{4}$ towards visible region can be done by varying Ti:Zr weight ratio [10], creating hollow sphere shape [11] and doping with $\mathrm{Bi}_{2} \mathrm{O}_{3}$ [12] However, all results still had relatively high bandgap (above $3.0 \mathrm{eV}$ ). Castillo et al. have successfully synthesized iron doped $\mathrm{TiO}_{2}$ nanoparticles by using $\mathrm{FeSO}_{4} \cdot 7 \mathrm{H}_{2} \mathrm{O}$ as an iron source [13]. In this research, Fe-doped $\mathrm{ZrTiO}_{4}$ will be synthesized by sol-gel method. Various iron concentrations as a dopant were introduced into the $\mathrm{ZrTiO}_{4}$ system and calcined at different temperatures to observed the optical properties of the resulted Fe-doped $\mathrm{ZrTiO}_{4}$. A certain amount of iron in $\mathrm{ZrTiO}_{4}$ system with optimum calcination temperature is expected to result in Fe-doped $\mathrm{ZrTiO}_{4}$ with high responsive towards sunlight.

\section{- EXPERIMENTAL SECTION}

\section{Materials}

Titanium(IV) tetraisopropoxide (TTIP) (97\%, Sigma-Aldrich) and zirconia $\left(\mathrm{ZrO}_{2}\right)$ fine powder (Jiaozuo Huasu) were used as precursors for synthesizing the photocatalyst material. Iron(II) sulfate heptahydrate $\left(\mathrm{FeSO}_{4} \cdot 7 \mathrm{H}_{2} \mathrm{O}\right)$ (Merck) was used as the dopant source. Solvents were absolute ethanol (PA, Merck) and demineralized water (Jaya Sentosa).

\section{Instrumentation}

Crystal structures of the samples were analyzed with X-ray powder diffractometer (XRD) PANalytical X'Pert PRO MRD. Surface structure was observed with scanning electron microscopy equipped with energy dispersive $\mathrm{X}$ ray spectrometer (SEM-EDX) JSM-6510LA. FourierTransform infrared spectrometer (FT-IR) analysis was conducted using Thermo Nicolet iS10. Ultraviolet and visible (UV-Vis) absorption of the samples were measured by specular reflectance UV-Vis spectrophotometer (SRUV) UV1700 Pharmaspec.

\section{Procedure}

First, $2.5 \mathrm{~mL}(8.2 \mathrm{mmol})$ of TTIP was dissolved in
$25 \mathrm{~mL}$ of absolute ethanol, while 1 gram $(8.1 \mathrm{mmol})$ of $\mathrm{ZrO}_{2}$ powder was dissolved in $25 \mathrm{~mL}$ of demineralized water. A certain amount of iron salts $(1,3,5,7$ and 9 wt.\%) was also dissolved into $\mathrm{ZrO}_{2}$ suspension. Then, the suspension was dropped into TTIP solution under mild stirring and followed by vigorous stirring for 30 min [14]. The suspended solid was separated by centrifugation at a rate of $1500 \mathrm{rpm}$ for $1 \mathrm{~h}$. Obtained solid was aged at $27^{\circ} \mathrm{C}$ for $48 \mathrm{~h}$ and then heated at $50{ }^{\circ} \mathrm{C}$ for $24 \mathrm{~h}$. The composite material was calcined at 500,700 and $900{ }^{\circ} \mathrm{C}$ under atmospheric condition for $4 \mathrm{~h}$.

\section{- RESULTS AND DISCUSSION}

Fe-doped $\mathrm{ZrTiO}_{4}$ had been successfully synthesized. Fig. 1 shows the diffraction pattern of various iron contents in $\mathrm{ZrTiO}_{4}$ together with reference materials $\mathrm{ZrO}_{2}$ and $\mathrm{TiO}_{2}$. All of the samples were calcined at $500{ }^{\circ} \mathrm{C}$. $\mathrm{ZrO}_{2}$ reference corresponds to a monoclinic structure (JCPDS: $37-1484$ ) as characteristic diffraction peaks appeared at $24.1^{\circ}(011), 28.2^{\circ}(-111)$, $31.5^{\circ}$ (111) and $34.1^{\circ}(002)$. No metastable tetragonal pattern was observed. Only anatase structure (JCPDS: 21-1272) appeared in $\mathrm{TiO}_{2}$ reference at $25.4^{\circ}$ (101). Fedoped $\mathrm{ZrTiO}_{4}$ samples had strong monoclinic $\mathrm{ZrO}_{2}$ pattern, while anatase pattern was hardly observable and no iron pattern. It happened because of the amount of iron and $\mathrm{TiO}_{2}$ in $\mathrm{Fe}$-doped $\mathrm{ZrTiO}_{4}$ are very small compared to $\mathrm{ZrO}_{2}$. Fe-doped $\mathrm{ZrTiO}_{4}$ diffractions reveal that the relative intensity of anatase peak around $25^{\circ}$ (101) decreased from 18 to $9 \%$, as iron content increased. It may be caused by iron dopant promoting phase transformation of anatase into rutile [15]. Another report suggests that $\mathrm{Zr}^{4+}$ inhibits the anataserutile transformation [16]. $\mathrm{ZrO}_{2}$ probably hinders the formation of rutile; thus there was no rutile peak observed.

Fig. 2 shows the diffraction pattern of $5 \% \mathrm{Fe}$-doped $\mathrm{ZrTiO}_{4}$ calcined at different temperatures together with reference materials consisting $\mathrm{TiO}_{2}$ at different calcination temperatures and $\mathrm{ZrO}_{2}$ after $500^{\circ} \mathrm{C}$ calcination. Same as the previous description, the diffraction pattern of $\mathrm{ZrO}_{2}$ and $\mathrm{TiO}_{2}$ after $500{ }^{\circ} \mathrm{C}$ calcination only showed monoclinic and anatase, respectively. $\mathrm{TiO}_{2}$ after $700{ }^{\circ} \mathrm{C}$ 


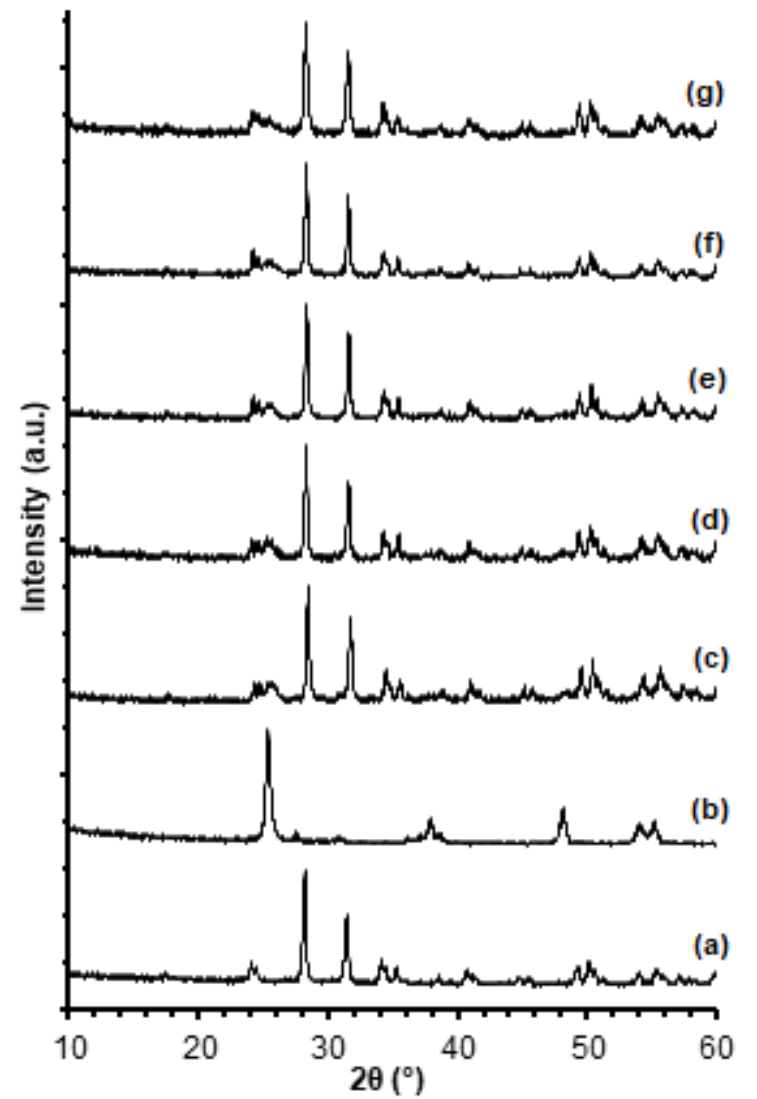

Fig 1. Diffraction pattern of (a) $\mathrm{ZrO}_{2}$, (b) $\mathrm{TiO}_{2}, \mathrm{ZrTiO}_{4}$ with (c) $1 \%$, (d) $3 \%$, (e) $5 \%$, (f) $7 \%$ and (g) $9 \%$ of $\mathrm{Fe}$ content after calcination at $500{ }^{\circ} \mathrm{C}$
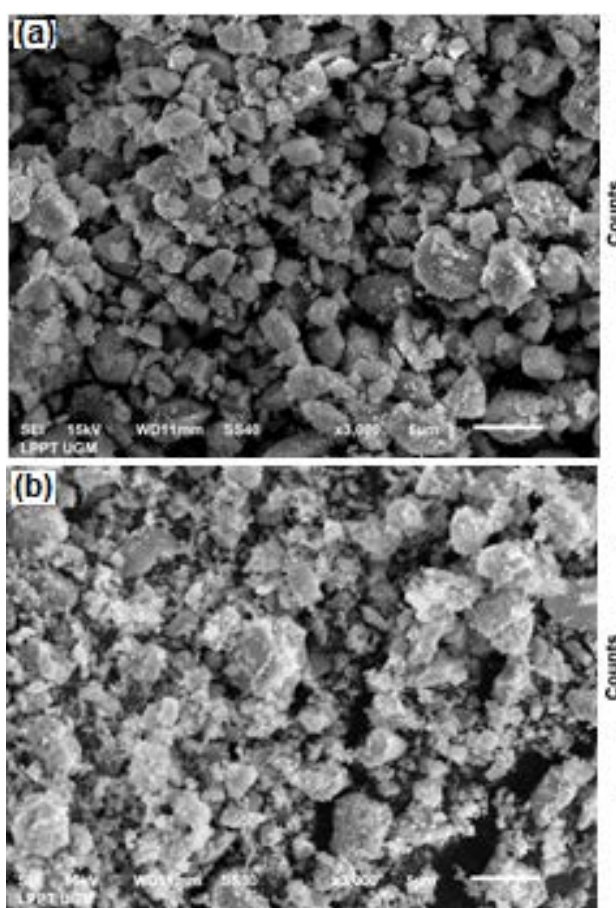

Fig 3. SEM images and EDX spectra of (a) $\mathrm{ZrO}_{2}$ and (b) $5 \% \mathrm{Fe}$-doped $\mathrm{ZrTiO}_{4}$ after calcination at $700{ }^{\circ} \mathrm{C}$

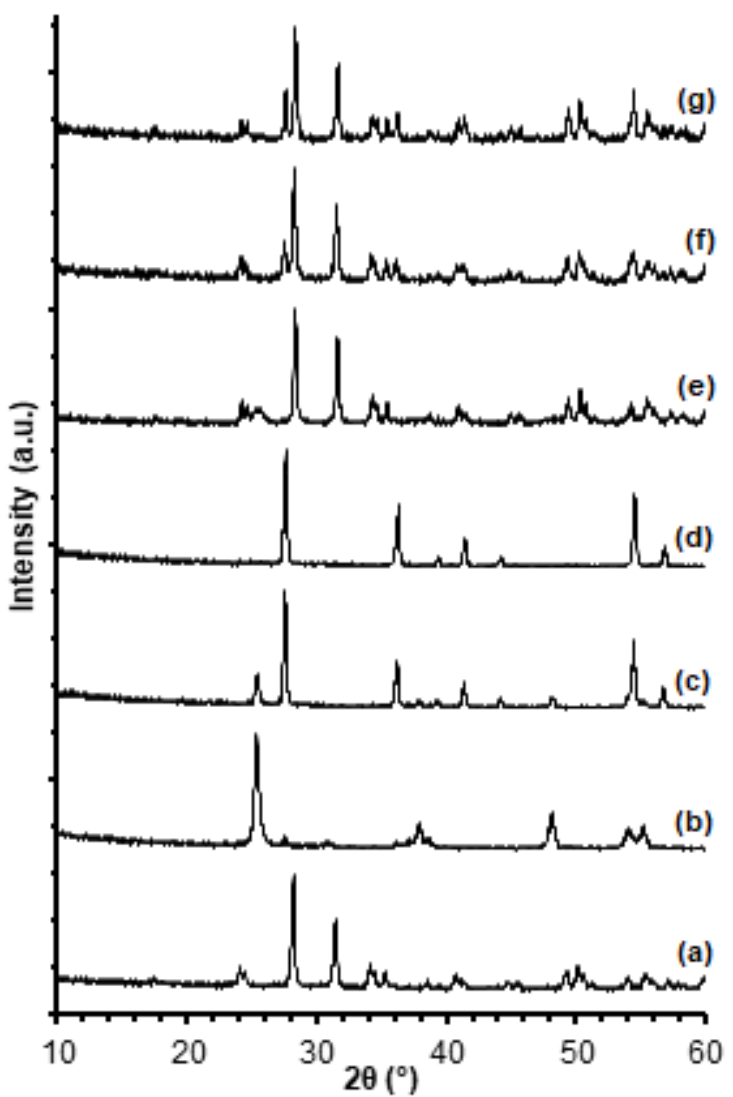

Fig 2. Diffraction pattern of (a) $\mathrm{ZrO}_{2} 500{ }^{\circ} \mathrm{C}, \mathrm{TiO}_{2}$ (b) $500{ }^{\circ} \mathrm{C}$, (c) $700{ }^{\circ} \mathrm{C}$, (d) $900{ }^{\circ} \mathrm{C}, 5 \% \mathrm{Fe}$-doped $\mathrm{ZrTiO}_{4}$ (e) $500{ }^{\circ} \mathrm{C}$, (f) $700{ }^{\circ} \mathrm{C}$ and (g) $900{ }^{\circ} \mathrm{C}$
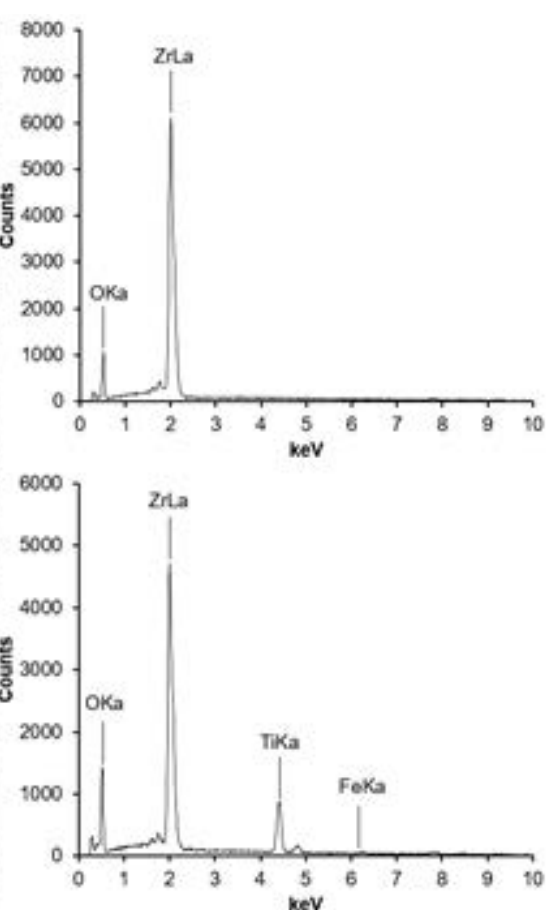
calcination showed characteristic rutile pattern (JCPDS: $21-1276)$ at $27.6^{\circ}(110), 36.2^{\circ}(101), 41.4^{\circ}(111)$ and $54.5^{\circ}$ (211), while the intensity of anatase pattern at $25.5^{\circ}(101)$ and $48.2^{\circ}(200)$ decreased. Only rutile pattern appeared in diffraction of $\mathrm{TiO}_{2}$ after $900^{\circ} \mathrm{C}$. The diffraction pattern of Fe-doped $\mathrm{ZrTiO}_{4}$ samples revealed that rutile structure starts to appear after $700{ }^{\circ} \mathrm{C}$ calcination corresponding to rising peak at $27.5^{\circ}(110)$ and $36.1^{\circ}(101)$. Anatase pattern was completely disappeared as the intensity of rutile pattern arose at $\mathrm{Fe}$-doped $\mathrm{ZrTiO}_{4}$ after $900^{\circ} \mathrm{C}$ calcination.

Fig. 3 presents SEM images and corresponding EDX analysis of $\mathrm{ZrO}_{2}$ and $5 \%$ Fe-doped $\mathrm{ZrTiO}_{4}$ after calcination at $700{ }^{\circ} \mathrm{C}$. The surface of Fe-doped $\mathrm{ZrTiO}_{4}$ was more rugged than $\mathrm{ZrO}_{2}$, due to iron and $\mathrm{TiO}_{2}$ deposition. It was confirmed with EDX analysis in Fig. 3, summarized in Table 1. The observed percentage of iron was very small, thus explains its absence in the X-ray diffraction pattern. The difference between measured and theoretical iron percentage is due to chemical equilibrium during the sol-gel reaction. Sol-gel reaction was performed without controlling the $\mathrm{pH}$. Not all iron(II) precipitated into the formed sol. The amount of iron added while preparation was purposely excess due to anticipating the chemical equilibrium by reaction condition. Metal should be introduced in a small amount to obtain an optimal doping effect. The ratio of $\mathrm{Zr}$ to $\mathrm{O}$ became lower than in $\mathrm{ZrO}_{2}$ due to the presence of $\mathrm{TiO}_{2}$ on the surface of iron-doped $\mathrm{ZrTiO}_{4}$. Fe-doped $\mathrm{ZrTiO}_{4}$ particles looked similar to $\mathrm{ZrO}_{2}$ particles with an estimated diameter around $2-5 \mu \mathrm{m}$.

Fig. 4 presents FT-IR spectra of various iron dopant concentrations in $\mathrm{ZrTiO}_{4}$ with $\mathrm{ZrO}_{2}$ and $\mathrm{TiO}_{2}$ as references. All the samples were calcined at $500{ }^{\circ} \mathrm{C}$. Vibration band around $3400 \mathrm{~cm}^{-1}$ appearing in all samples are identified as $\mathrm{O}-\mathrm{H}$ vibration. $\mathrm{ZrO}_{2}$ vibrational band at $740 \mathrm{~cm}^{-1}$ is attributed to $\mathrm{Zr}-\mathrm{O}_{2}-\mathrm{Zr}$ asymmetric mode of monoclinic [17]. The vibrational band around $490 \mathrm{~cm}^{-1}$ belongs to $\mathrm{Zr}-\mathrm{O}$ vibration [1]. The broad vibrational band around $500 \mathrm{~cm}^{-1}$ of reference $\mathrm{TiO}_{2}$ is designated to stretching vibration of Ti-O mode [18]. There is a vibrational band that appeared and increased around $1120 \mathrm{~cm}^{-1}$ as iron concentration arose on Fedoped $\mathrm{ZrTiO}_{4}$ spectra. It may belong to either $\mathrm{Fe}-\mathrm{O}-\mathrm{Zr}$ or $\mathrm{Fe}-\mathrm{O}-\mathrm{Ti}$, or also possibly both.
Table 1. EDX analysis of $\mathrm{ZrO}_{2}$ and $5 \%$ Fe-doped $\mathrm{ZrTiO}_{4}$ after calcination at $700{ }^{\circ} \mathrm{C}$

\begin{tabular}{llllll}
\hline \multirow{2}{*}{ Samples } & \multicolumn{5}{c}{$\%$ Mass } \\
\cline { 2 - 6 } & $\mathrm{Zr}$ & $\mathrm{O}$ & $\mathrm{Ti}$ & $\mathrm{Fe}$ & Total \\
\hline $\mathrm{ZrO}_{2}$ & 73.49 & 26.51 & - & - & 100 \\
$5 \%$ Fe-doped $\mathrm{ZrTiO}_{4}$ & 52.36 & 34.08 & 12.72 & 0.85 & 100 \\
\hline
\end{tabular}

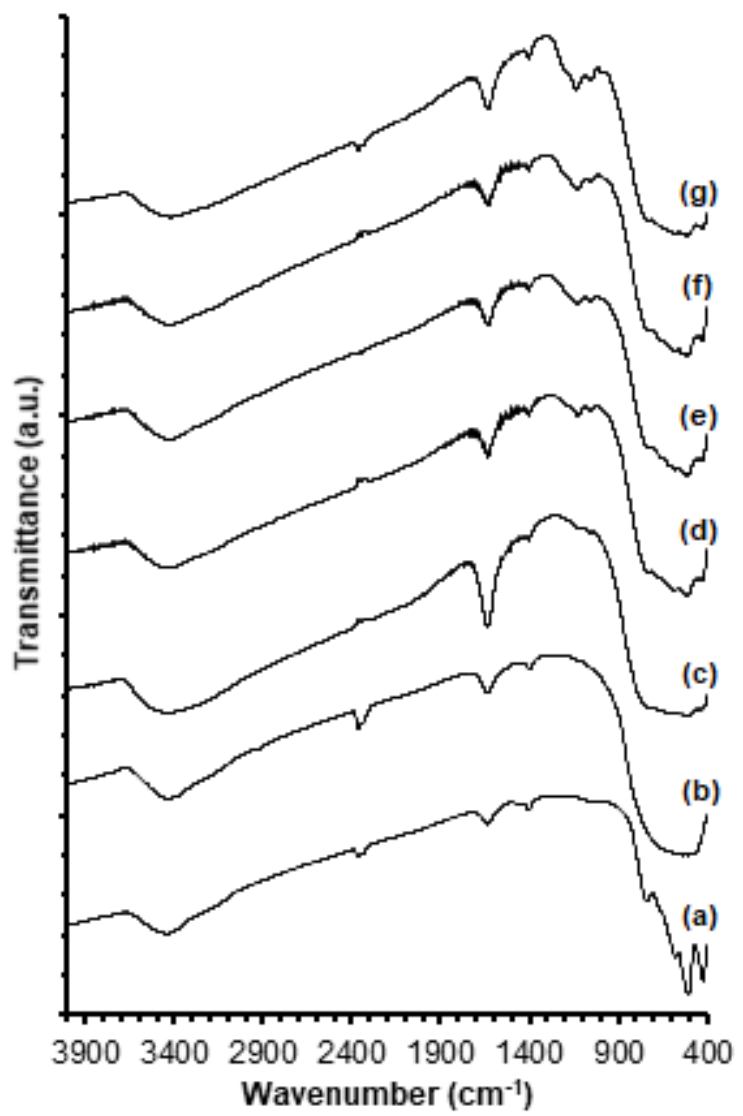

Fig 4. FT-IR spectra of (a) $\mathrm{ZrO}_{2}$, (b) $\mathrm{TiO}_{2}$ and $\mathrm{ZrTiO}_{4}$ with (c) $1 \%$, (d) $3 \%$, (e) $5 \%$, (f) $7 \%$ and (g) $9 \%$ of $\mathrm{Fe}$ content after calcination at $500{ }^{\circ} \mathrm{C}$

Fig. 5 presents FT-IR spectra of iron-doped zirconium titanate after calcination at different temperatures with $\mathrm{TiO}_{2}$ and $\mathrm{ZrO}_{2}$ as references. Higher calcination temperature on $\mathrm{TiO}_{2}$ reduces the intensity of $\mathrm{O}-\mathrm{H}$ vibration at $3400 \mathrm{~cm}^{-1}$ and sharpens $\mathrm{Ti}-\mathrm{O}$ stretching mode around $500 \mathrm{~cm}^{-1}$. The iron dopant vibration band on the samples around $1120 \mathrm{~cm}^{-1}$ decreased as calcination temperature increased. This possibly happened because of the iron dopant that sinters at a higher temperature, thus the $\mathrm{Fe}-\mathrm{O}$ vibration weakens. 


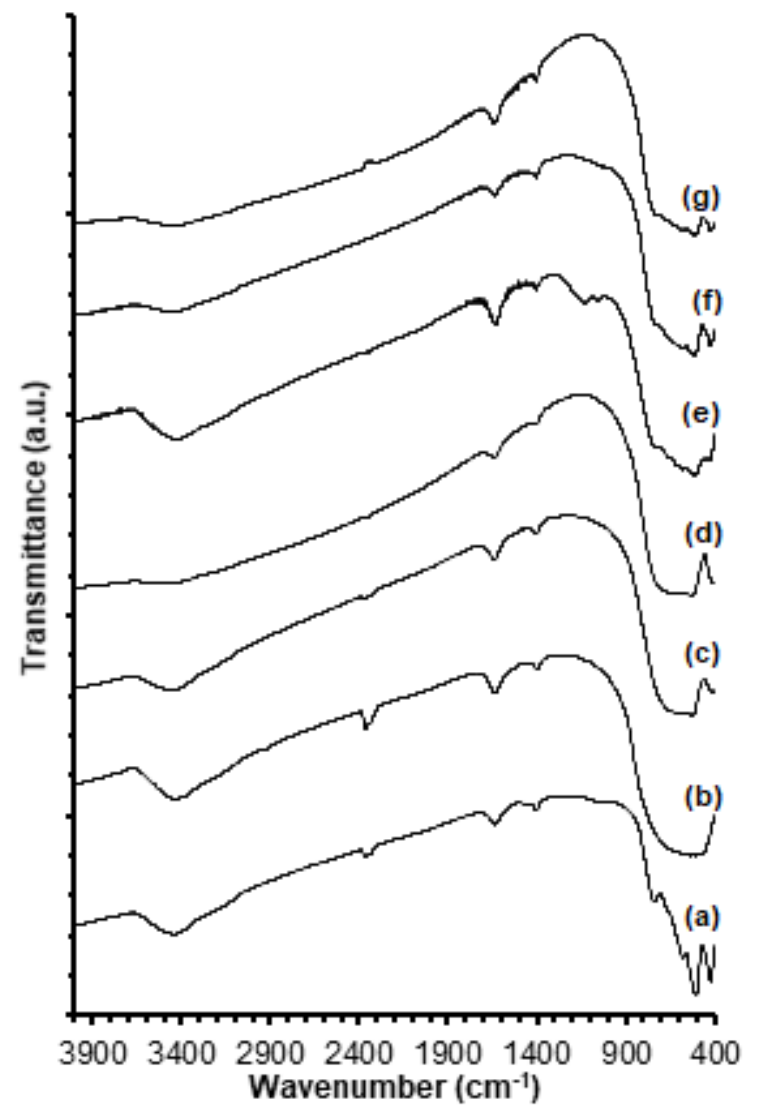

Fig 5. FT-IR spectra of (a) $\mathrm{ZrO}_{2} 500{ }^{\circ} \mathrm{C}, \mathrm{TiO}_{2}$ (b) $500{ }^{\circ} \mathrm{C}$, (c) $700{ }^{\circ} \mathrm{C}$, (d) $900{ }^{\circ} \mathrm{C}, 5 \% \mathrm{Fe}$-doped $\mathrm{ZrTiO}_{4}$ (e) $500{ }^{\circ} \mathrm{C}$, (f) $700^{\circ} \mathrm{C}$ and $(\mathrm{g}) 900^{\circ} \mathrm{C}$

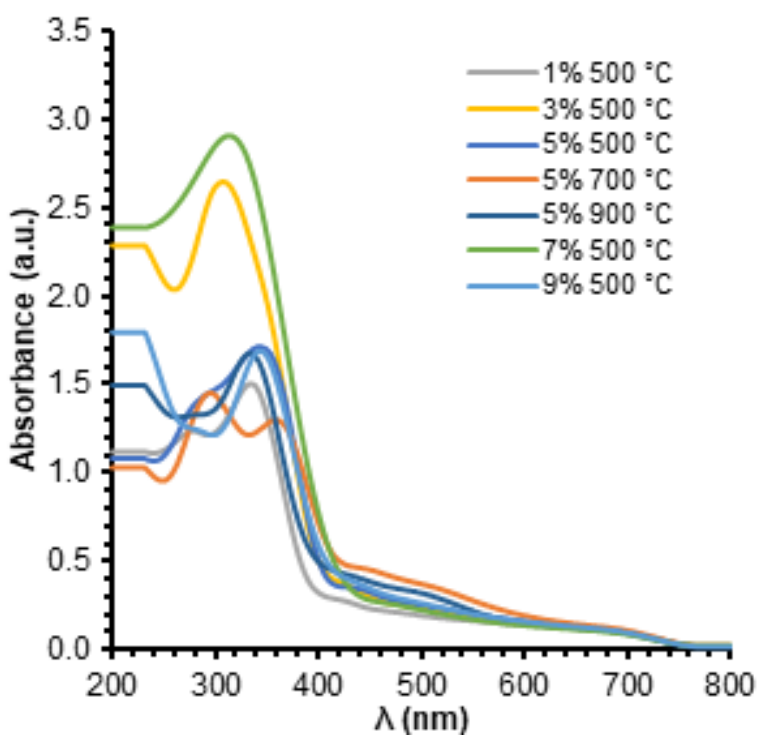

Fig 6. UV-Vis absorption spectra of various Fe-doped $\mathrm{ZrTiO}_{4}$
Table 2. Bandgap data of Fe-doped $\mathrm{ZrTiO}_{4}$ with $\mathrm{ZrO}_{2}$ and $\mathrm{TiO}_{2}$

\begin{tabular}{lc}
\hline Sample & $\mathrm{E}_{\mathrm{g}}(\mathrm{eV})$ \\
\hline $\mathrm{ZrO}_{2} 500^{\circ} \mathrm{C}$ & 3.23 \\
$\mathrm{TiO}_{2} 500{ }^{\circ} \mathrm{C}$ & 3.02 \\
$\mathrm{Fe}$-doped $\mathrm{ZrTiO}_{4} 1 \% 500^{\circ} \mathrm{C}$ & 2.96 \\
$\mathrm{Fe}$-doped $\mathrm{ZrTiO}_{4} 3 \% 500^{\circ} \mathrm{C}$ & 2.88 \\
$\mathrm{Fe}$-doped $\mathrm{ZrTiO}_{4} 5 \% 500^{\circ} \mathrm{C}$ & 2.85 \\
$\mathrm{Fe}$-doped $\mathrm{ZrTiO}_{4} 5 \% 700{ }^{\circ} \mathrm{C}$ & 2.93 \\
$\mathrm{Fe}$-doped $\mathrm{ZrTiO}_{4} 5 \% 900^{\circ} \mathrm{C}$ & 2.97 \\
$\mathrm{Fe}$-doped $\mathrm{ZrTiO}_{4} 7 \% 500^{\circ} \mathrm{C}$ & 2.83 \\
Fe-doped $\mathrm{ZrTiO}_{4} 9 \% 500{ }^{\circ} \mathrm{C}$ & 2.88 \\
\hline
\end{tabular}

The bandgap of photocatalyst material can be obtained by analyzing spectral data of UV-Vis absorption. Bandgap relates to the absorption edge of the photocatalyst. Spectral data of photocatalyst material generally consist of single or more absorption peaks. Absorption edge can be determined by finding a turning point which exhibits minimum absorbance at the edge of the absorption peak. Fig. 6 shows UV-Vis absorption spectra of iron-doped $\mathrm{ZrTiO}_{4}$, whereas Table 2 summarizes the bandgap value from UV-Vis absorption data analysis. All Fe-doped $\mathrm{ZrTiO}_{4}$ samples exhibited lower bandgap than $\mathrm{ZrO}_{2}$ and $\mathrm{TiO}_{2}$. The iron dopant is proved to decrease the indirect bandgap of $\mathrm{ZrTiO}_{4}$ as iron content increases from 1 to $7 \%$. The new energy level is formed between the valence and conduction band of $\mathrm{ZrTiO}_{4}$. As the iron concentration increased, the density of new energy levels formed also increased, thus lowering the bandgap. The bandgap increased from 7 to $9 \%$, due to the heterojunction effect that cancels the doping effect. The bandgap of $\mathrm{ZrTiO}_{4}$ with 5\% of iron content increased as the calcination temperature was increased. This phenomenon probably happened because iron dopant is sintered. There are two peaks appearing on the samples that had been calcined at 700 and $900{ }^{\circ} \mathrm{C}$. Those two peaks are attributed to the monoclinic and rutile phase.

Based on the optical properties, all Fe-doped $\mathrm{ZrTiO}_{4}$ is expected to be responsive towards the visiblelight region. Due to its relatively small bandgap, 
Fe-doped $\mathrm{ZrTiO}_{4}$ should be a potential candidate as photocatalyst material under sunlight irradiation.

\section{- CONCLUSION}

Iron-doped zirconium titanate had been successfully synthesized by sol-gel method. XRD characterization signifies that iron concentration and calcination temperature alter the phase composition of the iron-doped $\mathrm{ZrTiO}_{4}$ composite. The presence of $\mathrm{TiO}_{2}$ and iron on $\mathrm{ZrTiO}_{4}$ surface were proved by SEM-EDX. Doping of iron into $\mathrm{ZrTiO}_{4}$ shifts the bandgap to be lower than $\mathrm{ZrO}_{2}$ and $\mathrm{TiO}_{2}$, which is believed to be more responsive towards visible region. On the contrary, higher calcination temperature induces the iron-doped $\mathrm{ZrTiO}_{4}$ to be more responsive towards the UV region. $\mathrm{ZrTiO}_{4}$ with $7 \%$ iron after calcination at $500{ }^{\circ} \mathrm{C}$ happens to have the lowest bandgap $\left(\mathrm{E}_{\mathrm{g}}=2.83 \mathrm{eV}\right)$. Thus, making it possible to apply the composite as a catalyst under visiblelight irradiation.

\section{- ACKNOWLEDGMENTS}

We would like to express our gratitudes to The Ministry of Research, Technology and Higher Education of the Republic of Indonesia for their support on this works through PDUPT 2018 Grant (73/UN1/DITLIT/ DIT-LIT/LT/2018).

\section{- REFERENCES}

[1] Agorku, E.S., Kuvarega, A.T., Mamba, B.B., Pandey, A.C., and Mishra, A.K., 2015, Enhanced visible-light photocatalytic activity of multi-elements-doped $\mathrm{ZrO}_{2}$ for degradation of indigo carmine, J. Rare Earths, 33 (5), 498-506.

[2] Reddy, C.V., Babu, B., Reddy, I.N., and Shim, J., 2018, Synthesis and characterization of pure tetragonal $\mathrm{ZrO}_{2}$ nanoparticles with enhanced photocatalytic activity, Ceram. Int., 44 (6), 6940-6948.

[3] Chen, J., Qiu, F., Xu, W., Cao, S., and Zhu, H., 2015, Recent progress in enhancing photocatalytic efficiency of $\mathrm{TiO}_{2}$-based materials, Appl. Catal., A, 495, 131-140.

[4] Rahimi, N., Pax, R.A., and Gray, E.M.A., 2016, Review of functional titanium oxides. $\mathrm{I} \mathrm{TiO}_{2}$ and its modifications, Prog. Solid State Chem., 44 (3), 86105.

[5] Pelaez, M., Nolan, N.T., Pillai, S.C., Seery, M.K., Falaras, P., Kontos, A.G., Dunlop, P.S.M., Hamilton, J.W.J., Byrne, J.A., O’Shea, K., Entezari, M.H., and Dionysiou, D.D., 2012, A review on the visible light active titanium dioxide photocatalysts for environmental applications, Appl. Catal., B, 125, 331-349.

[6] Chang, D.A., Lin, P., and Tseng, T.Y., 1995, Optical properties of $\mathrm{ZrTiO}_{4}$ films grown by radiofrequency magnetron sputtering, J. Appl. Phys., 77 (9), 4445.

[7] Navio, J.A., Colón, G., and Herrmann, J.M., 1997, Photoconductive and photocatalytic properties of $\mathrm{ZrTiO}_{4}$. Comparison with the parent oxides $\mathrm{TiO}_{2}$ and $\mathrm{ZrO}_{2}$, J. Photochem. Photobiol., A, 108 (2-3), 179-185.

[8] Oanh, L.T.M., Ha, D.H., Hue, M.M., Hang, L.T., Thang, D.V., Hung, N.M., Phuong, D.T., and Minh, N.V., 2015, Effects of crystallinity and particle size on photocatalytic performance of $\mathrm{ZrTiO}_{4}$ Nanostructured Powders, VNU J. Sci., 31 (4), 49-55.

[9] Botta, S.G., Navío, J.A., Hidalgo, M.C., Restrepo, G.M., and Litter, M.I., 1999, Photocatalytic properties of $\mathrm{ZrO}_{2}$ and $\mathrm{Fe} / \mathrm{ZrO}_{2}$ semiconductors prepared by a sol-gel technique, J. Photochem. Photobiol., A, 129, 89-99.

[10] Badli, N.A., Ali, R., Wan Abu Bakar, W.A., and Yuliati, L., 2017, Role of heterojunction $\mathrm{ZrTiO}_{4} / \mathrm{ZrTi}_{2} \mathrm{O}_{6} / \mathrm{TiO}_{2}$ photocatalyst towards the degradation of paraquat dichloride and optimization study by Box-Behnken design, A rabian J. Chem., 10 (7), 935-943.

[11] Syoufian, A., Manako, Y., and Nakashima, K., 2015, Sol-gel preparation of photoactive srilankite-type zirconium titanate hollow spheres by templating sulfonated polystyrene latex particles, Powder Technol., 280, 207-210.

[12] Neppolian, B., Kim, Y., Ashokkumar, M., Yamashita, H., and Choi, H., 2010, Preparation and properties of visible light responsive $\mathrm{ZrTiO}_{4} / \mathrm{Bi}_{2} \mathrm{O}_{3}$ 
photocatalysts for 4-chlorophenol decomposition, $J$. Hazard. Mater., 182 (1-3), 557-562.

[13] Carrera-López, R., and Castillo-Cervantes, S., 2012, Effect of the phase composition and crystallite size of sol-gel $\mathrm{TiO}_{2}$ nanoparticles on the acetaldehyde photodecomposition, Superf. vacío, 25 (2), 82-87.

[14] Kurniawan, R., 2018, Synthesis of Iron Doped Zirconium Titanate as Potential Visible-Light Photocatalyst with Various Dopant Concentrations and Calcination Temperatures, Master Thesis, Department of Chemistry, Universitas Gadjah Mada, Yogyakarta.

[15] Rauf, M.A., Meetani, M.A., and Hisaindee, S., 2011, An overview on the photocatalytic degradation of azo dyes in the presence of $\mathrm{TiO}_{2}$ doped with selective transition metals, Desalination, 276 (1-3), 13-27.

[16] Venkatachalam, N., Palanichamy, M., Arabindoo, B., and Murugesan, V., 2007, Enhanced photocatalytic degradation of 4-chlorophenol by $\mathrm{Zr}^{4+}$ doped nano $\mathrm{TiO}_{2}$, J. Mol. Catal. A: Chem., 266 (1-2), 158-165.

[17] Sahu H.R., and Rao, G.R., 2000, Characterization of combustion synthesized zirconia powder by UVvis, IR and other techniques, Bull. Mater. Sci., 23 (5), 349-354.

[18] Thangavelu, K., Annamalai, R., and Arulnandhi, D., 2013, Preparation and characterization of nanosized $\mathrm{TiO}_{2}$ powder by sol-gel precipitation route, Int. J. Emerging Technol. Adv. Eng., 3 (1), 636-639. 